\section{Liverpool Learned Societies}

THE newly issued handbook of the Associated Learned Societies of Liverpool and District shows there are about four thousand members of the twentyfour scientific, industrial, literary, art and educational societies in the association. One of the largest of the industrial societies, the Liverpool Engineering Society, has some seven hundred members, and the Liverpool Naturalists' Field Club is the largest of the Nature and outdoor societies. Since the last handbook was issued ten years ago, the number of learned societies in the association has fallen by two. Local societies which have increased their membership in the past ten years are the British Association of Chemists, the Institute of Chemistry and the Liverpool Naturalists' Field Club; those that have remained at the same strength include the local branch of the Pharmaceutical Society and the Amateur Photographic Association, while those that have declined in membership somewhat include the Liverpool Botanical Society, Geological Society, Biological Society, Literary and Philosophical Society, Astronomical Society, Engineering Society, Lancashire and Cheshire Entomological Society, Society of Chemical Industry and the New Education Fellowship. The Associated Learned Societies of Liverpool and District was formed in 1922, though since 1880 there had been a scheme of co-operation between local societies, chiefly for staging annual exhibitions and soirées of their activities. The work of the present association includes holiday prize contests in the local schools, outdoor and indoor joint meetings of an educational nature, periodical public scientific exhibitions, lectures, etc., and various schemes for closer co-operation amongst the various learned societies of the district.

\section{Research and the Jute Industry}

THe prosperity of Bengal, both agricultural and industrial, is dependent very largely on jute, and the intense period of depression which has overtaken the industry since 1929 has caused widespread distress. The Agricultural Commission, of which the present Viceroy was chairman, in a strongly worded paragraph of its report, directed attention to the necessity for the application of scientific methods in the industry ; the position has since been surveyed by Dr. S. G. Barker. In the March issue of Science and Culture, Dr. Barker's report is discussed. Dr. Barker has recommended a comprehensive scheme of research which includes the establishment of a laboratory with arrangements for the collection of general and technical information and for foreign representation. This new organization is estimated to cost $£ 27,000$ per annum, and it would be under the control of the Jute Mills Association. Science and Culture appears to doubt whether the control suggested by Dr. Barker is likely to prove successful, since it is feared that the mill owners may be prone to look for immediate financial returns. It is suggested that a scheme organized on the lines of the Indian Central Cotton Committee might be more advantageous. In view of the urgency of the problem, we regard the nature of the controlling body to be of minor importance, since the success of the scheme will depend mainly upon the director of research and upon the personnel of the new laboratory. It is gratifying, therefore, to learn that the Government of India has already accepted Dr. Barker's proposals, and that it has appointed an Indian Central Jute Committee. The Committee will be financed by Government, which will place at its disposal approximately $£ 30,000$ per annum for a minimum period of five years. We extend a cordial welcome to this new research organization, which we have no doubt will do much to restore the ancient prosperity of Bengal.

\section{Road Transport Vehicles}

Instructrve figures are given in World Power of June showing the relative progress made by the three principal types of road transport vehicles-tramways, motor-buses and trolley-buses. In 1930-31, tramways transported $\mathbf{7 2 \cdot 7}$ per cent of all passengers, the motor-bus $24 \cdot 2$ per cent and the trolley-bus $3 \cdot 1$ per cent. In 1934-35 the figures were 59 per cent, 35 per cent and 6 per cent respectively. Although the tramways with 2,479 million passengers in 1934-35 still convey more persons than the motor-bus and trolleybus combined, the decline of tramway passengers since $1930-31$, when it was 3,018 millions, has been continuous. During the year 1935, the number of passengers carried by the trolley-buses was 255 millions, an increase of 36 per cent on the preceding year. The London Passenger Transport Board recently reported an increase of 20 per cent in the London area along trolley-bus routes. It has been calculated that an oil-driven bus would require a 250 horse-power engine to equal the performance of a 100 horse-power trolley-bus with a capacity of 36 seats carrying a full load up a 7 per cent gradient at a speed of 30 miles per hour. From the point of view of national economy, it is a pity, although trolley-bus progress is satisfactory, that it is not making more rapid headway. In the near future, it may be of primary importance to consume homeproduced fuel to produce the necessary motive power for traction. When the traffic is very heavy, electric tramways are the most economical, but tram-cars often stop the traffic to unload passengers, whilst trolley-buses can unload them directly on the pave. ment.

\section{A Horticultural Colour Chart}

THE naming of colour is notoriously difficult, and it is unfortunate that the standard works by Ridgway, Oberthur and Dauthenay, and others, are either out of print or too expensive to have wide application. Gardeners are, perhaps, the community most in need of a comprehensive manual portraying accurate shades of colour, and the Royal Horticultural Society is to be congratulated upon its attempt to meet this pressing need. It is proposed to print a volume of a hundred colours, each in four shades, and, if successful, to follow it by a second volume of similar dimensions. The plates would be either loose in a cover, or held by a loose-leaf binder, and the estimated price is $10 \mathrm{~s}$. 